\title{
Lightweight Concrete Using Local Industrial By-product
}

\author{
Deborah Olukemi Olanrewaju \\ Department of Building Technology, Lagos State Polytechnic, Lagos +234 , Nigeria
}

Received: March 31, 2014 / Accepted: April 15, 20114 / Published: June 25, 2014.

\begin{abstract}
Construction is one of the largest users of energy, material resources and water and it is a formidable polluter. One of the major materials used in construction is concrete and ordinary concrete contains about $12 \%$ cement which is a major producer of greenhouse gas in the world. The use of waste materials as partial replacement of cement in concrete reduces greenhouse gases, frees up land fill space, and reduces raw materials consumption. This contributes towards sustainable development, as in a sustainable society, nature is not subject to systematically increasing concentrations of substances extracted from the earth's crust. This research work explores the possibility of replacing some percentage of cement in concrete with marble sludge powder to produce lightweight concrete. This was achieved by determining the compressive strength and some hardened properties of concrete like sorptivity and carbonation with marble sludge. The results so far have been able to prove that lightweight concrete can be produced when some percentage of cement is replaced with this waste.
\end{abstract}

Key words: Lightweight concrete, marble sludge, filler, carbonation, permeation.

\section{Introduction}

Industrial by-products are waste materials produced by industries as a result of production. More production equals more waste, and more waste creates environmental concerns of toxic threat. An economically viable solution to this problem should include utilization of these waste materials for new products especially in construction applications which in turn minimizes the heavy burden on the nation's landfills, saves natural resources, energy, reduces air and water pollution and also reduces the emission of green house gases. Examples of these wastes that can be used in construction works which include cement kiln dust, foundry sand, fly ash, silica fume, slag, marble sludge, and so on [1].

By virtue of its size, construction is one of the largest users of energy, material resources and water, and it is a formidable polluter [2]. There is increasing concern now that the choice of construction materials must also be governed by ecological considerations.

Corresponding author: Deborah Olukemi Olanrewaju, M.Sc., research fields: building structure \& construction material research. E-mail: kemiolan@yahoo.com.
Concrete is the major construction material in the world with 11.5 billion tons of concrete as world demand per year and the demand for concrete is expected to grow to approximately 18 billion tons a year by 2050 [3].

Ordinary concrete, typically, contains about $12 \%$ cement, $8 \%$ mixing water, and $80 \%$ aggregate by mass [3]. This means that, in addition to 1.5 billion tons of cement, the concrete industry is consuming annually 9 billion tons of sand and rock together with one billion ton of mixing water. The 11.5 billion tons a year concrete industry is, thus the largest user of natural resources in the world which if continue unchecked will result in depletion of natural resources. Greenhouse gas is also generated which is responsible for $5 \% \mathrm{CO}_{2}$ production in the world. The mining, processing and transport of huge quantities of aggregate, in addition to billions of tons of raw materials needed for the cement manufacture consume considerable energy and adversely affect the ecology of virgin lands. If the waste product of one industry is recycled as a substitute for virgin raw material of another industry, it will thereby reduce the 
environmental impact of both. Any efforts to reduce such dependence of virgin materials will, therefore, be a contribution towards sustainable development.

Marble sludge powder is an industrial waste containing heavy metals in its constituent and it is produced from cutting of marble stone for usage in various construction applications in Nigeria. The amount of industrial waste generated due to the cutting is increasing every day; this put pressure on the limited number of land fill and suggests more sustainable use of such in construction development and in production of new products like concrete. The use of marble sludge as filler material in cement reduces the amount of natural resources required. This displaces some cement production, an energetically expensive and environmentally problematic process, while reducing both the need for land area for extracting resources and amount of industrial waste that must be disposed of.

In recent times, marble dusts have found some use in the construction industry and research has been conducted to examine their applications. An exclusive work has been done on the feasibility of the usage of quarry rock dust and marble sludge powder as hundred percent substitutes for natural sand in concrete [4]. From the study, it is found that the compressive, split tensile strength and durability studies of concrete made of quarry dust and marble sludge powder are nearly $14 \%$ more than the conventional concrete. The concrete resistance to sulphate attack was enhanced greatly, according to the experiment performed on the hardened properties of bituminous concrete with marble dust as filler [5]. Fillers are fine aggregate material that passes 0.063 $\mathrm{mm}$ sieve [6]. The behaviour of bituminous concrete with marble dust compared very well with bituminous concrete with lime and stone dust.

Marble powder has a very high Blaine finess value of about $1.5 \mathrm{~m}^{2} / \mathrm{g}$ with $90 \%$ of particles, passing 50 $\mu \mathrm{m}$ sieves and $50 \%$ under $7 \mu \mathrm{m}$ [7]. The maximum compressive and flexural strengths were observed for specimens containing $6 \%$ waste sludge when compared with control and it was also found that waste sludge up to $9 \%$ could effectively be used as an additive material in cement [8]. The result of an investigation on the abrasion resistance of concrete made by percentage substitution of sand by marble waste powder compared very well with that of conventional concrete [9]. In the same study, increment in percentage of substitution of sand caused a significant increment in the sodium sulphate resistance of concrete; whereas water penetration depth of concrete with marble powder at $15 \%$ substitution was found considerably less than that of concrete with 0 marble powder. Marble dust can also be used as filler and helps to reduce the total voids content in concrete [9]. Consequently, this contributes to improvement of strength of concrete.

The durability of concrete is a function of permeability [10], hence concrete can be made durable by reducing the extent of voids. Permeability is the movement of fluids across a porous medium as a result of pressure gradient. Thus, concrete permeability refers to its ability to transmit fluids through it caused by pressure head; this applies to the transport of both gases and liquid [11]. More research is still needed to see its wider application in concrete especially as partial replacement of cement. The objective of this study to provide more scientific evidence to support the re use of accumulated marble wastes in Nigeria; by investigating into the following hardened properties of concrete with marble sludge powders, compressive strength, permeability, sorptivity and carbonation. If this is successful there will be less demand on cement, thus providing possible solutions to environmental concerns of green house gas $\left(\mathrm{CO}_{2}\right)$ pollution, waste production and depletion of natural resources. The paper is organized as follows: Section 2 shows the characterization of materials; Section 3 explains the materials and experimental methods used in the study; Section 4 presents results and discussions; and Section 5 
highlights the conclusions.

\section{Characterization of Materials}

The physical characteristics of the marbles sludge powder are furnished in Table 1 while the chemical characteristics of the marble sludge powder are compared with that of ordinary Portland cement is in Table 2.

\section{Materials and Experimental Methods}

\subsection{Cement}

Ordinary Portland cement that conforms to ASTM C150 - standard specification for Portland cement obtained from a local commercial manufacturer in Nigeria precisely (Dangote cement) was used throughout the experiment.

\subsection{Marble}

Marble dust samples from Coker, Lagos State, Nigeria were crushed and grinded using laboratory crusher and ball mill and passes $0.063 \mathrm{~mm}$ sieve size.

\subsection{Aggregates}

The coarse aggregate used was crushed granite chippings with a size of $12 \mathrm{~mm}$ at the average.

Medium size fine aggregate from Ebute River in Ikorodu with clean tap water available in the concrete laboratory was used in manufacturing the concrete. The qualities of water samples are uniform and potable.

\subsection{Specimen's Preparation}

The batching of concrete was done by weighing the different constituent materials based on the adopted mix ration of $1: 2: 4$ and $1: 3: 6$. In the first ratio labeled mix A, cement was replaced by marble dust at $0,5,10$ and $20 \%$ (represented by mix codes $\mathrm{MA}_{1}, \mathrm{MA}_{2}, \mathrm{MA}_{3}$ and $\left.\mathrm{MA}_{4}\right)$. The same was done for the second ratio labeled mix $\mathrm{B}$ (represented by mix codes $\mathrm{MB}_{1}, \mathrm{MB}_{2}$, $\mathrm{MB}_{3}$ and $\left.\mathrm{MB}_{4}\right)$.

The water cement ratio for both two mixes was $0.65 \%$ by weight. The freshly mixed concrete was then filled in $150 \mathrm{~mm}$ by $150 \mathrm{~mm}$ moulds in approximately $50 \mathrm{~mm}$ layers with each layer given 35 strokes of the tamping rod. Samples were held in the laboratory at an atmosphere of more than $95 \%$ relative humidity and ambient temperature, i.e., $25{ }^{\circ} \mathrm{C}$. The moulds were opened after $24 \mathrm{~h}$ and the specimens were stored in the humid bath for 28 days curing age.

\subsection{Test Procedure}

The $150 \mathrm{~mm}$ size concrete cubes were used as test specimens to determine the compressive strength. The test specimen at the end of 28 curing days were subjected to compressive load from a $214 \times 250$ shambhavimpe compression testing machine until failure.

\subsection{Durability studies}

The object of this durability study is to investigate the permeability through sorptivity test and resistance to carbon attack for both conventional concrete and concrete with \% replacement of cement. Sorptivity test was conducted over six hours. The water sorptivity test measures the rate of movement of water front through the concrete under capillary suction. The specimens after dried were saw-cut in

Table 1 Physical characteristics of marble powder.

\begin{tabular}{lllclccc}
\hline Material & $\begin{array}{l}\text { Moisture } \\
\text { content }(\%)\end{array}$ & $\begin{array}{l}\text { Bulk } \\
\left(\mathrm{kg} / \mathrm{m}^{3}\right)\end{array}$ & $\begin{array}{r}\text { density Fineness } \\
\text { modulus }\end{array}$ & $\begin{array}{l}\text { Effective } \\
(\mathrm{mm})\end{array}$ & $\begin{array}{c}\text { size Coefficient } \\
\text { uniformity }\end{array}$ & $\begin{array}{l}\text { of Coefficient } \\
\text { gradation }\end{array}$ & of Wet dry \\
\hline Marble powder & 23.35 & 1.59 & 1,118 & 2.04 & 0.17 & 1.58 & 1.37 \\
\hline
\end{tabular}

Table 2 Chemical characteristics of marble sludge powder and Portland cement.

\begin{tabular}{lllllllll}
\hline Material & $\mathrm{Fe}_{2} \mathrm{O}_{3}$ & $\mathrm{MnO}$ & $\mathrm{Na}_{2} \mathrm{O}$ & $\mathrm{MgO}$ & $\mathrm{K}_{2} \mathrm{O}$ & $\mathrm{Al}_{2} \mathrm{O}_{3}$ & $\mathrm{CaO}$ & $\mathrm{SiO}_{2}$ \\
\hline & $\%$ wt & $\%$ wt & $\%$ wt & $\% w t$ & $\% w t$ & $\%$ wt & $\%$ wt & $\%$ wt
\end{tabular}




\begin{tabular}{|c|c|c|c|c|c|c|c|c|}
\hline Marble & 11.99 & 0.08 & 2.08 & 8.74 & 2.33 & 4.45 & 1.58 & 64.86 \\
\hline Portland cement & 2.27 & 0.045 & 0.75 & 2.24 & 0.70 & 5.86 & 64.07 & 20.15 \\
\hline
\end{tabular}

pieces $\left(75 \times 150 \mathrm{~mm}^{2}\right)$. The surfaces of the concrete samples were then placed in water. For each mass determination, the test specimens were removed from water and the surfaces cleaned with a dampened paper towel to remove water droplets. The mass of the samples were then measured and were replaced to continue the test. The cumulative change in mass 1,2 , $3,4,5$ and 6 hours were used to obtain the respective cumulative absorption values $(i)$ expressed as Eq (1):

$$
i=\Delta \mathrm{m} / \mathrm{A} \ell
$$

where, $\Delta m=$ cumulative change in mass due to water absorption, $A=$ cross-sectional area of test specimen $\left(\mathrm{mm}^{2}\right)$ and $\ell=$ density of water $\left(10^{3} \mathrm{~kg} / \mathrm{m}^{3}\right)$

As soon as concrete is formed, the carbon dioxide in the air reacts with the calcium hydroxide, forming calcium carbonate, a process known as carbonation. For the carbonation test of the samples, phenolphthalein indicator solution was applied to fresh fractured surface of concrete. The indicator turns purple at $\mathrm{PH}$ above 8.6 and remains colourless when the $\mathrm{PH}$ of the concrete is below 8.6, suggesting carbonation. A fully carbonated paste has a $\mathrm{PH}$ of about 8.4. In practice, strong immediate colour change to purple suggest a $\mathrm{PH}$ that is rather higher, perhaps PH 9.0 or 10.0 .

\section{Results and Discussion}

\subsection{Compressive Strength Development}

Compressive strength tests were conducted in accordance with BS EN12390-3:2009 [12] on all cubes of the two mixed ratios at 28 curing days. Compressive strength test results are shown in Table 3 and Fig.1. MDC (marble dust concrete) showed a reduction in compressive strength compared to the control PC concrete. This confirms that different mixes of concrete ingredients produce different strengths which are measured in MPa [13]. Different strengths of concrete are used for different purposes; very low-strength (14 MPa or less) concrete maybe used when the concrete must be lightweight [13].

Table 3 Average compressive strength in $\mathrm{N} / \mathrm{mm}^{2}$ at 28 days.

\begin{tabular}{lllll}
\hline \multirow{2}{*}{ MIX } & \multicolumn{4}{c}{ \% Marble concentration } \\
\cline { 2 - 5 } & 0 & 5 & 10 & 20 \\
\hline MIX A & 29.3 & 20.5 & 19.6 & 19.1 \\
MIX B & 24 & 15.3 & 15.1 & 9.6 \\
\hline $\begin{array}{l}\text { 4.2 Applications } \\
\text { Construction }\end{array}$ & of & Lightweight & Concrete in & in
\end{tabular}

- Curtain walls for high-rise construction;

- Highway sound barriers;

- Low cost insulated walls for residential buildings;

- Tilt up panels;

- Façade tiles for an architectural application;

- Repairs on a bridge;

- Slope protection;

- Aircraft arresting beds;

- Foundations for roads and sidewalks;

- Subsurface for sport arenas, e.g., tennis courts;

- Explosion-resistant structures.

\subsection{Permeation Test}

Sorptivity test was conducted over six hours and the cumulative change in mass at specific intervals was determined. The results in Fig. 2 show decrease in sorptivity as the level of replacement of cement increases. This means marble dust can be used as filler and helps to reduce the total voids content in concrete. This result is in line with Ref. [9].

\subsection{Carbonation Test}

Phenolphthalein indicator solution was used to achieve the carbonation test. There was strong immediate colour change to purple in all the samples which suggest a $\mathrm{PH}$ that is rather higher perhaps $\mathrm{PH}$ 9.0 or 10.0 , but within 24 hours, the specimen begin to turn colourless. The result of carbonation test of MDC 
compares very well with control concrete. The

MDC. This improves the compressive and tensile penetration rate of carbonation increases with increase in exposure time for all samples with faster rate in

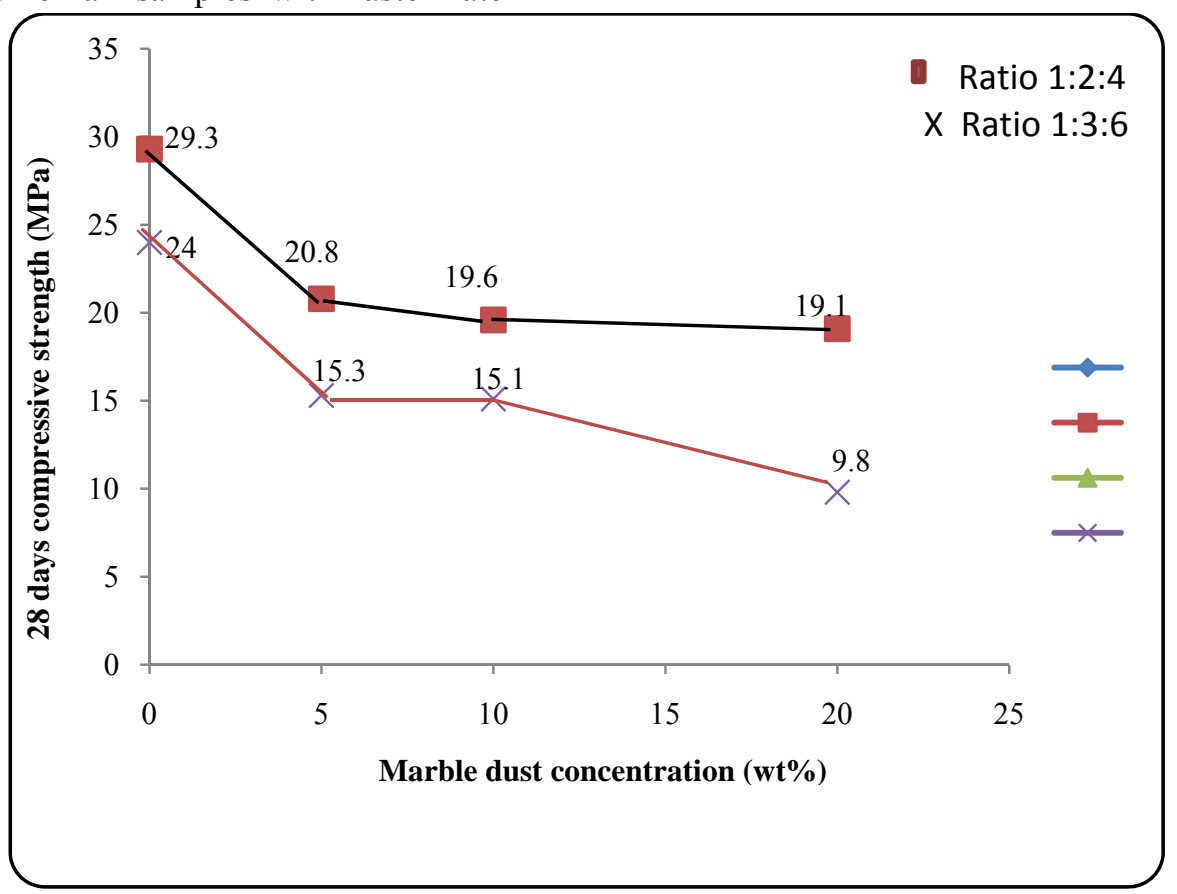

Fig. 1 Compressive strength of concrete samples.

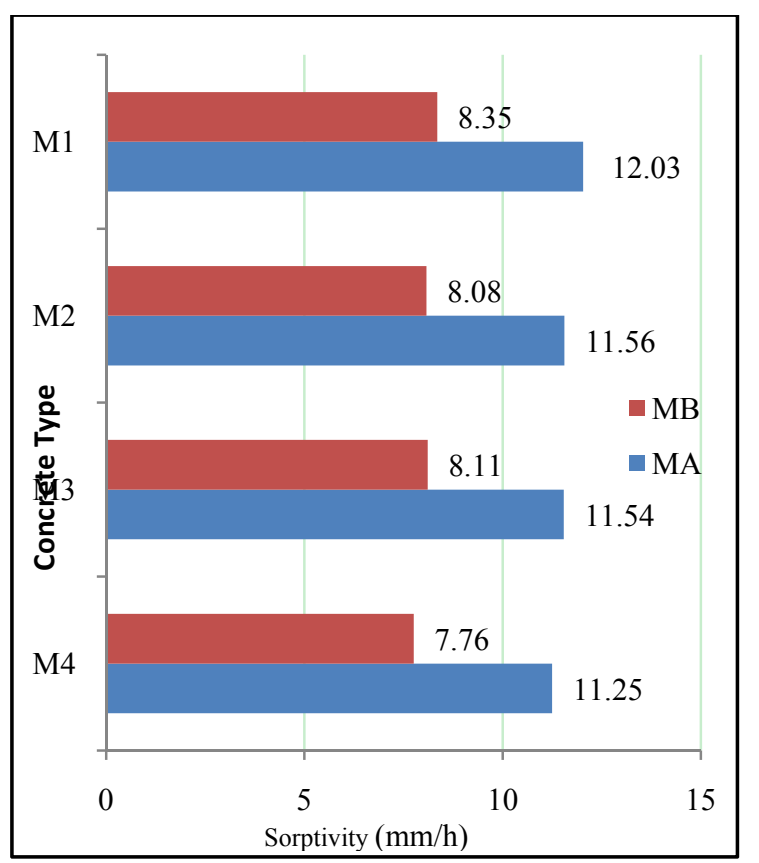

Fig. 2 Sorptivity and concrete type.

strength of concrete by reducing the porosity of dense and compact concrete, protecting it against water and chloride ion infiltration. Chloride ions can corrode the steel placed in reinforced concrete. It is important to keep these advantages in mind because the carbonation is an inevitable process for concrete to undergo.

\section{Conclusions}

From the above study, it is concluded that the marble sludge powder may be used as a partial replacement material for cement in producing lightweight concrete. The investigation was primarily to find solution to the disposal problem of marble dust. The disposal of this waste material can lead to the following environmental problems:

- If the waste is disposed on soils, the porosity and permeability of top soil will be reduced, the fine marble dust reduces the fertility of the soil by increasing its alkalinity;

- When dumped, marble powder suspends in the air and slowly spread out through wind to the nearby area;

- When dumped along a catchment area of natural rainwater, it results in contamination of over ground water reservoir and also causes drainage problem. 


\section{Acknowledgements}

The author thanks the members of Yaba College of Technology Concrete Workshop staff for providing the needed support for the success of this research work.

\section{References}

[1] B. Johnny, A. Taher, F. Ellie, Utilization of recycled and waste materials in various construction applications, American Journal of Environmental Sciences 9 (1) (2013) 14-24.

[2] H. Arpad, Construction Materials and Environment, Annu. Rev. Environ. Resource (29) (2004) 181-204.

[3] P.K. Mehta, P.J.M. Monteiro, Concrete: Microstructure, Properties and Materials, McGraw-Hill Professional, USA, 2013.

[4] H.M. Shahul, A.S.S. Sekar, Properties of green concrete containing quarry rock dust and marble sludge powder as fine aggregate, ARPN Journal of Engineering and Applied Sciences 4 (4) (2009) 83-89.

[5] C. Satish, R. Choudhary, Performance characteristics of bituminous concrete with industrial wastes as filler, Journal of Materials in Civil Engineering 25 (11) (2013) 1666-1673.
[6] BSI. BS EN 197-1:2000, Cement Composition, Specification and Conformity Criteria for Common Cements.

[7] C. Valeria, M. Giacomo, R.N. Tarun, Characterisation of Marble powder for its use in mortar and concrete, in: NMET/ACI International Symposium on Sustainable Development of Cement and Concrete, Toronto, Canada, Oct. 5-7, 2005.

[8] T. Salih, Physico-chemical treatment of marble processing wastewater and the recycling of its sludge, Materials Science and Engineering 419 (1-2) (2006) 306-309.

[9] H. Houari, H. Hebhoub, H. Aoun, M. Belachia, Use of waste marble aggregates in concrete, Construction Build Mater 25 (2011) 1167-1171.

[10] B. Bogale, Comparison of concrete durability as produced by various cements manufactured in Ethiopia, M.Sc. Thesis, Addis Ababa University School of Graduate Studies, 2007.

[11] Literature Review Summary Increased Mineral Addition Online, http://www4.umw.edu/cbu/papers/200320CBU20 Reports/REP-525-pdf.

[12] BSI. BS EN 12390-3: 200, Testing Hardened ConcreteCompressive Strength of Test.

[13] Structural Lightweight Concrete-Concrete Construction, The Aberdeen Group, Mar. 1981. 